\title{
潮汐波の水粒子速度計測のための差温式微流速計

\author{
TEMPERATURE GRADIENT-TYPE MICRO FLOWMETER FOR THE \\ MEASUREMENT OF WATER PARTICLE VELOCITY OF TIDAL WAVE
}

\author{
高木不折*・和田 清**・中村俊六***
}

By Fusetsu TAKAGI, Kiyoshi WADA and Shunroku NAKAMURA

\begin{abstract}
A temperature gradient-type micro flowmeter has been devised to measure water particle velocity less than $1 \mathrm{~cm} / \mathrm{s}$ appearing in the flow condition in the tidal current field. The fundamental characters and applicability of the flowmeter for the flow condition mentioned above has been discussed theoretically and experimentally, especially on the problem such as its sensitivity, response character and calibration. Through the present paper, although there remains the difficulty due to the nonlinear response of the flowmeter to time variation of the velocity, it turned out that the flowmeter can be applied to measure the very low velocity. The flowmeter devised here can give us a useful tool to discuss the such problem as the hydraulic mechanism of the tidal and residual current fields.
\end{abstract}

Keywords: flow measurement, micro flowmeter, heat advection, tidal current, water particle velocity

\section{1. 序 論}

著者らはここ数年, 潮汐に起因する湾内の流動場につ いて実験的な検討を進めている．その際，水理模型内の 流れは流速ゼロを中心とする往復振動流となるが，模型 縮尺の変化により流れが乱流域にある時間的割合（乱流 度）は異なり，小縮尺では，層流の範囲内にとどまるこ ともある1)。このような緩流域の潮流場では, 弱非線形 過程に従う潮汐残渣流が物質輸送に関して重要であると 考えられている21. それは, 潮流の 1 周期時間平均とし て移流項から出てくる 2 次流であり, その潮流場の内部 構造の計測は, 潮汐残渣流の生成・維持機構を明らかに するうえで必要不可欠である.

流速計としては，種々のものがあり，すでに多くの検 討が加えられている31.4). しかしながら, 非接触計測で あるレーザー流速計などを別にすると, 層流境界層に起 因する潮汐残渣流の生成・維持機構の解明を目的とした 緩流速のオイラー的計測に用いるのには，従来の流速計 はいくつかの難点がある，その原因は，このような湾内

* 正会員 工博 名古屋大学教授 工学部土木工学科 ( ₹464 名古屋市千種区不老町)

** 正会員 工修 名古屋大学助手 工学部土木工学科(同上)

*** 正会員 工博 豊橋技術科学大学助教授 工学部建設 工学系 ( T440 皚橋市天伯町雲雀ケ丘 1-1)
の流れは,

i ）往復流であること,

ii）非常に微流速の状態か現われること，

などであろう。したがって, 微流速における出力信号と ノイズとの比（ $S N$ 比）をできるだけ大きくし，ノイズ やドリフトの混入の影響を少なくする必要がある.

そこで，このような目的に合致し，しかも比較的安価 で，安定性の高い流速計として，著者らは，トレーサー 法を原理とする差温式のものに注目した。そそれ，従来 の流速計の多くが流速が小さくなると極端にその測定精 度が低下するのに対し, 差温式微流速計 ${ }^{51}$ は流速が小さ くなるとかえって測定精度を向上し得るという性質を もっているからである．本論文では試作した差温式流速 計について特に緩流域での流速に対するその応答特性を 実用上の観点から検討する.

\section{2. 差温式微流速計の作動原理}

\section{（1）流速測定の基礎式}

$x, y$ 方向平面二次元の定常流れの中に連続熱源があ る場合を考えると，そこに生じる温度場での熱移流拡散 方程式は,

$$
\frac{\partial T}{\partial t}=K\left(\frac{\partial^{2} T}{\partial x^{2}}+\frac{\partial^{2} T}{\partial y^{2}}\right)-u \frac{\partial T}{\partial x}-v \frac{\partial T}{\partial y} \cdots \cdots \cdots \cdots(1)
$$




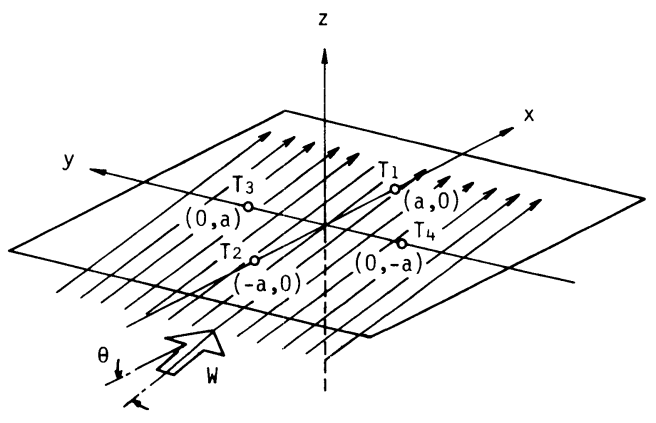

图一1 座模系および記号の定義

と記される.ここで, $x, y$ : 流れ場の座標, $t$ : 時間, $T:$ 温度, $u, v: x, y$ 方向の流速成分, $K$ : 熱拡散係 数（一定）である.

いま，図一1に示すように熱源が $x-y$ 平面に垂直な $z$ 軸上 $(x, y)=(0,0)$ の無限線状熱源であるとし, そ の単位長さ単位時間当りの発生熱量を $q$ とする. ただ し，ここでいう発生熱量は熱容量で割ったものである. また，流れ場が， $x, y, z$ いずれの方向にも無限の広が りをもち定常であって, さらに流速べクトル $W$ が $x$ 方 向に対して迎角 $\theta$ をもつ二次元の場合には, $t \rightarrow \infty$ の 定常温度場に対して, 式 (1) の解は6),

$$
T=\frac{q}{2 \pi K} e^{\alpha x+\beta y} \cdot K_{0}\left(\sqrt{\alpha^{2}+\beta^{2}} \cdot r\right)
$$

となる。ただし， $\alpha=u / 2 K, \beta=v / 2 K, r^{2}=x^{2}+y^{2}$, $W^{2}=u^{2}+v^{2}, K_{0}\left(\sqrt{\alpha^{2}+\beta^{2}} \cdot r\right): 0$ 次の第 2 種変形 Bessel 関数である.

したがって $x$ 軸上の 2 点 $(a, 0),(-a, 0)$ および $y$ 軸上の 2 点 $(0, a),(0,-a)$ の温度をそれぞれ $T_{1}$, $T_{2}, T_{3}, T_{4}$ とすると, $x, y$ 方向における 2 点の無次元 温度差 $\Delta T_{12}, \Delta T_{34}$ は，それぞれ

$$
\begin{aligned}
& \Delta T_{12}=\frac{T_{1}-T_{2}}{q / 2 \pi K}=\left(e^{\alpha a}-e^{-\alpha a}\right) K_{0}\left(\sqrt{\alpha^{2}+\beta^{2}} \cdot a\right) \cdots(3) \\
& \Delta T_{34}=\frac{T_{3}-T_{4}}{q / 2 \pi K}=\left(e^{\beta a}-e^{-\beta a}\right) K_{0}\left(\sqrt{\alpha^{2}+\beta^{2}} \cdot a\right) \cdots(4)
\end{aligned}
$$

となる.この式は， $a, q$ および $K$ が与えられれば, 温 度差 $T_{1}-T_{2}$ および $T_{3}-T_{4}$ から $\alpha, \beta$, すなわち $u, v$

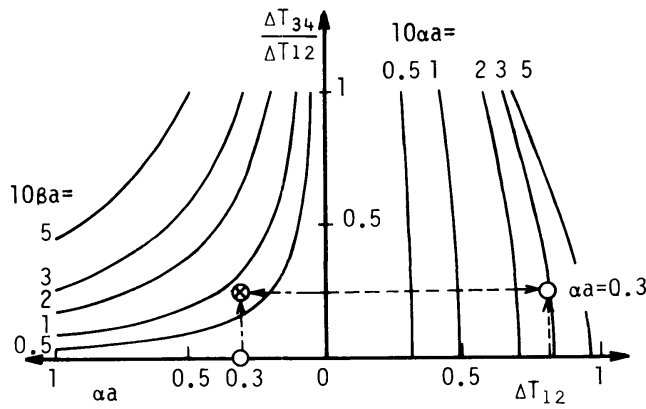

図一2 無次元流速 2 成分および温度差の関係
が求められることを示している. また熱源と $2 つ$ つ温度 検出部までの距離が異なる場合でも, 温度差 $T_{1}-T_{2}$ 等 のゼロ点がずれるだけで基本的には同じである.

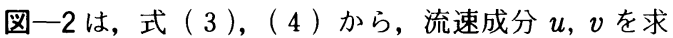
める手順を示している. つまり, $\Delta T_{12}$ と $\Delta T_{34} / \Delta T_{12}$ の 関係からまず $\alpha a$ を求め, その $\alpha a$ と $\Delta T_{34} / \Delta T_{12}$ から $\beta a$ が決定される.

\section{（2）流速計の感度}

簡単のため, 流れ方向が $x$ 軸と一致した一次元の場 合を考える. 式（3）を流速 $u$ について微分すると,

$$
\begin{aligned}
\frac{\partial\left(T_{1}-T_{2}\right)}{\partial u}= & \frac{q a}{4 \pi K^{2}}\left[\left(e^{\alpha a}+e^{-\alpha a}\right) K_{0}(\alpha a)\right. \\
& \left.-\left(e^{\alpha a}-e^{-\alpha a}\right) K_{1}(\alpha a)\right] \cdots \cdots . .
\end{aligned}
$$

となる.ここで, $K_{1}(\alpha a)$ は 1 次の第 2 種変形 Bessel 関 数である. 図一-3は式 (3), (5) を無次元化して示し たものである. 同図からわかるように, $\alpha a=0$ すなわち $u=0$ のときに流速に対する無次元温度差 $\Delta T_{12}$ の変化 率は無限大となり, $\alpha a=0.78$ のとき, $\Delta T_{12}$ は最大で, $\alpha a$ すなわち流速に対するその変化率はゼロとなり, 以 後流速の増加に応じて $\Delta T_{12}$ は減少する。 このように流 速に対する温度差の応答は非線形ではあるが， $\alpha a<$ 0.78 の範囲では 1 価関数となるので, 流速がこの範囲 内にある場合にはこの流速計を用いることができる. し かも，ここで注目すべき点は流速が小さくなるほど，流 速に対する温度差の変化率が大きいことであって，これ は流速が小さいほど流速計としての感度が高くなること を示している.

\section{3. 試作した差温式微流速計の基本特性}

\section{（1）流速計の構成}

差温式微流速計は, 当初土鍧中の水分フラックスを直 接測定する装置として開発されたものであるが7,8), 流 体中に適用するためにはいくつかの改良を必要とした.

本研究で式作した差温式微流速計の主要構造部分を示 したものが図一4であり，センサー部（図a）と回路部

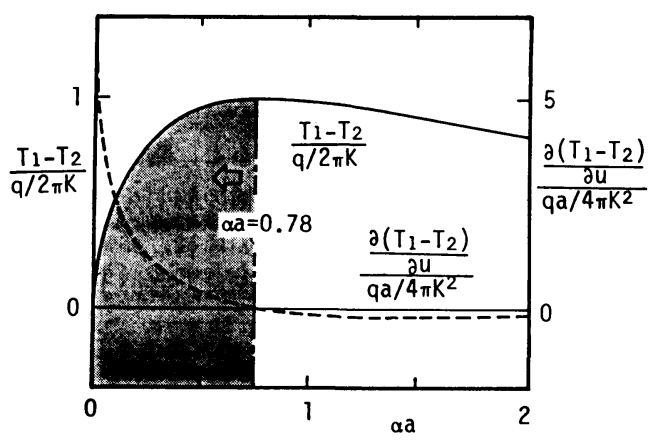

図一3 無次元流速と温度差およびその变化率の関係 
（図c）とから構成されている.

図一3からもわかるように, $K=$ 一定の場合, 1 価関 数の成立する限界值 $(\alpha a)_{\text {crit. }}$ （図では0.78）は $u, a$ の みの関数となり, 流速 $u$ の測定範囲を広げるためには, 間隔 $a$ を小さくする必要がある. その結果流速計の時 定数は小さくなり，周波数応答特性および感度の向上が 期待される. 一方, 従来土堙中の水分フラックス測定に 用いられてきたものは, 1 方向成分を抽出する形となっ ており, 主流方向が確定している場合にのみ適用可能で あった．したがって，2.（1）で述べたような任意方向 の流速成分の検出のためには，温度測定部を 2 組垂直に 配置しなければならない. ところが，図一1のように 1 本の熱源の周囲に 4 本の測定部を配置すると, 温度測定 部の支柱の影響などにより流れの状態が乱れる可能性が ある.このため，著者らはそれぞれ図一4(a) のような 1 本の熱源と 2 つの温度測定部をもつ 2 組を作り, それ らを図一4(b) のように離して配置することにした.な お, 温度検出部と熱源部との間隔 $a$ については指向性 などの点から小さすぎても問題があるため, $a=4,5,6$ $\mathrm{mm}$ の 3 通りについて検討した結果, 感度, 指向性など の点から $a=5 \mathrm{~mm}$ の場合を採用した。ただし，図一1 において流速ベクトル $W$ が $x$ 軸と一致する $\theta=0^{\circ}$ の場 合には, $a=4 \mathrm{~mm}$ では 1 価関数の成立する最大流速值 は $1.0 \mathrm{~cm} / \mathrm{s}$ 程度である.

センサー部は, 内部にサーミスター（温度 $0^{\circ} \mathrm{C}:$ 抵 抗 $15 \mathrm{k} \Omega, 100^{\circ} \mathrm{C}: 0.5 \mathrm{k} \Omega, B$ 值 [サーミスタ一定数] : 3400 )を埋め込んだ外径 $2 \mathrm{~mm}$, 内径 $1.5 \mathrm{~mm}$ の 3 本の

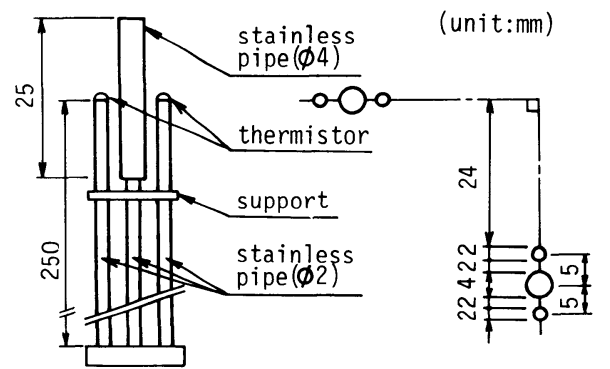

(a)

(1) (3) input

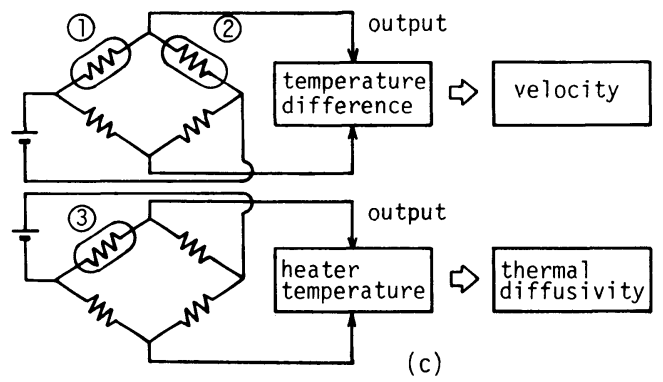

図一4 差温式微流速計の主要粠造部分
ズテンレスパイプからなり, パイプの中心間隔は $a=5$ $\mathrm{mm}$ に固定し，それを 2 組垂直に配置している. 中央の パイプには熱源として直径 $0.32 \mathrm{~mm}$, 長さ $60 \mathrm{~cm}$ の二 クロム線を絶縁してから巻きつけ，熱源の污濁による影 響を少なくし，流速が増加してもある程度温度差が生じ るように外径 $4 \mathrm{~mm}$ のステンレスパイプで被覆し，これ に0.6Aの定電流を流して加熱するようにした。

回路部は, 2 つのサーミスターがブリッジ回路の 2 辺 をなすように組み込まれており，回路へは $0.1 \mathrm{~mA}$ の定 電流を流し，抵抗のバランスのくずれによる電位差から 温度差, さらに熱源中に挿入したサーミスターから温度 が測定できるようになっている.

\section{（2）流速計の応答特性}

流速計に要求される応答特性は, 全周波数域に一様で ある必要はなく，研究対象をとらえ得る特性であれば十 分である. 従来流速計の応答速度の目安として時定数が よく用いられるが，それはもともと慣性のきかない系に 関する量であり，ステップ状の入力に対しては時間的に 指数変化することが知られている ${ }^{9}$.

本研究では, 流速計のステップ応答を, 滑動可能な台 車に流速計を取り付け，台車を急に滑動および停止させ た場合の出力値の変動状況を通して調べた.

図一 5 は, その出力值の時間変化について, 実際の出 力例（図a）およびその模式図（図b）を示したもので ある. 図a からわかるように，台車の滑動開始直前まで の出力値 $\left(V_{s}\right)$ の時間変化は安定しており, 滑動直後に 出力値はスパイク的に応答し, 最大值に達した後, ほぼ 安定した值 $\left(V_{r}\right)$ まで減衰する.ここで, 図bに示した

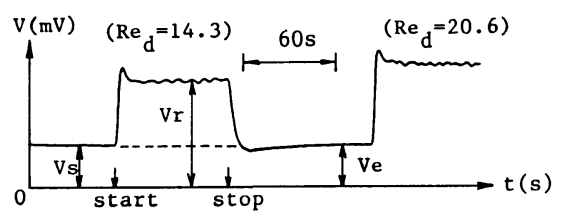

(a)

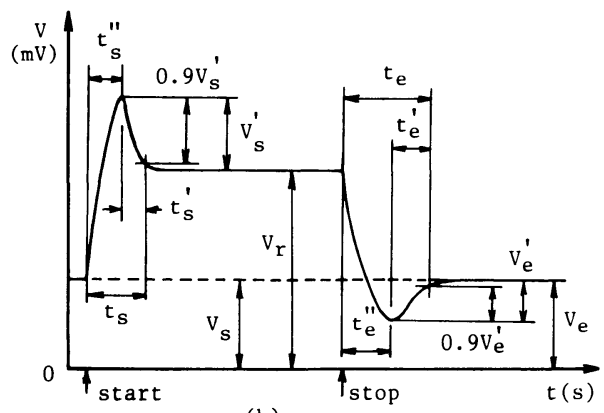

(b)

図一5応答実験における出力值の時間变化の実剆例（a) およびその模式図 (b) 
ように滑動開始から最大出力値までの時間 $t_{s}^{\prime \prime}$, および その最大値と滑動後安定した一定出力値の差 $V_{s}^{\prime}$ に対し て, 出力値が $90 \%$ 変化するのに要する時間 $t_{s}^{\prime}$ の和之 して滑動時定数 $\left(t_{s}\right)$ を定義する. また, 台車の停止後急 激に出力値は最小値まで低下するが滑動開始直後の場合 よりも, 極值以後の変化状況は緩やかであり, 滑動停止 後の安定した值 $\left(V_{e}\right)$ まで回復する. 同様にして, 停止 時定数 $\left(t_{e}\right)$ を求める.

このように, 滑動開始前後の出力差 $\left(V_{s}-V_{e}\right)$ は 0 に 近く, 滑動中の出力值もほぼ一定していることから, 流 速計のトレンドは無視できるほど小さく，安定している ことがわかる. また本流速計は, 速度変化に対して敏感 に応答し，ほとんど時間遅れなしでとらえることができ るが, その絶対値を求める場合，急激な変化に対しては 流速計のタイムラグを考慮する必要がある.

図一6 は, 時定数 $t_{s}, t_{e}$ と円柱 Reynolds 数 $\left(R_{e_{d}}\right)$ と の関係を表わしたものである，ただし，

$$
R_{e_{d}}=U \cdot d / \nu
$$

ここで, $U$ : 台車速度, $d:$ 熱源のステンレスパイプ径, $\nu$ : 動粘性係数である.

同図から， $R_{e_{d}}$ の増加とともに $t_{s}, t_{e}$ は若干小さくな る傾向があるが, Kármán 渦の発生限界といわれている $R_{e_{d}}=40$ 以後は後流の影響が含まれている可能性がある ので10), この範囲のプロットは除外して考えれば， $t_{s}$, $t_{e}$ はそれぞれほぼ一定とみることができる.そこで, $R_{e_{d}}<40$ に対してそれぞれ算術平均すれば時定数の平均 值として $t_{s}=7.0 \mathrm{~s}, t_{e}=9.0 \mathrm{~s}$ を得る. なお, $t_{s}<t_{e}$ と なるのは, 出力が最大値あるいは最小値に達した後に一 定値に安定するまでの時間が異なるからである．すなわ ち，図一 5 に示した記号を用いれば，主として $t_{s}^{\prime}<t_{e}^{\prime}$ であることに起因している.

\section{（3）基本的検定}

a) 温度検出部の検定

温度検出部（サーミスター）の検定にあたっては, 温

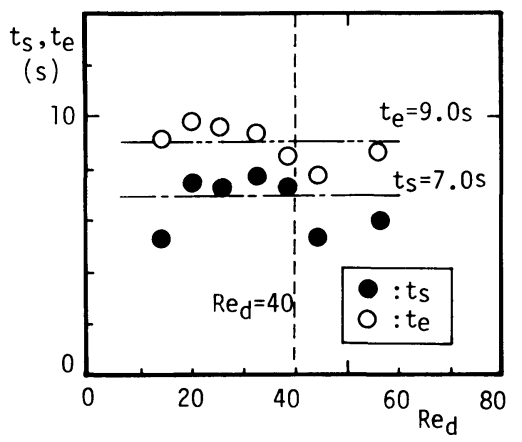

図一6 答実験におけるレイノルズ数 $\boldsymbol{R}_{e_{d}}$ と時定数 $t_{s}, t_{e}$ の関係
度安定器とサーモスタットを用いた恒温水槽に, 水晶温 度計と自作の温度センサーを入れて行った. 水晶温度計 は分解能 $0.001^{\circ} \mathrm{C}$, 測定誤差 $0.01^{\circ} \mathrm{C}$ であり, 恒温水槽 は $0.01^{\circ} \mathrm{C}$ 程度の誤差で温度を一定に保つことができ る.

一般に温度検出部の抵抗と絶対温度との間には, 次の 関係がある ${ }^{11}$.

$$
R_{i}=R_{0 i} \exp B_{i}\left(\frac{1}{T_{t}}-\frac{1}{T_{0}}\right)
$$

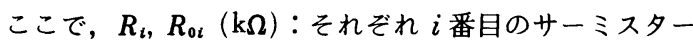
の周囲温度 $T_{i}, T_{0}(\mathrm{~K})$ における抵抗値, $B_{i}$ : サーミス ター定数である.

また，図一7のようなブリッジ回路を考え， $R_{1}$ をサー ミスターの抵抗值とすると, $C, D$ 間の電位差 $V$ は, 直 流電圧を $E$ として,

$$
\frac{V}{E}=\frac{V_{c}-V_{D}}{E}=\varepsilon-\frac{R_{01} \exp B_{1}\left(1 / T_{1}-1 / T_{0}\right)}{R_{2}+R_{01} \exp B_{1}\left(1 / T_{1}-1 / T_{0}\right)}
$$

となる. ここで, $\varepsilon=R_{3} /\left(R_{3}+R_{4}\right)$ である. 温度 $T$ と電 位差 $V$ の関係を図一8に示す. 同図から $T$ と $V$ は 15 $\sim 30^{\circ} \mathrm{C}$ の範井内では上に凸の曲線で表わされ，この関 係から，熱源の温度を測定することができる. 同様にし て, $R_{1}, R_{2}$ をサーミスターの抵抗值として,

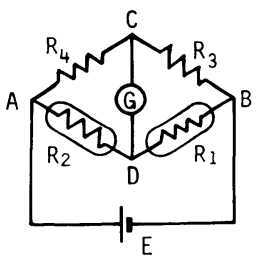

図一7 ブリッジ回路

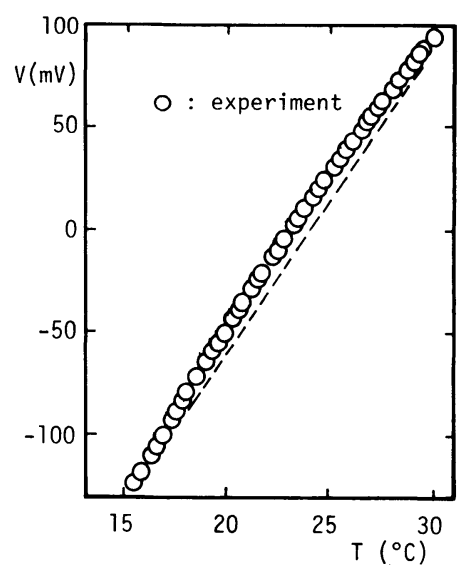

図一8 温度と出力值の関係 


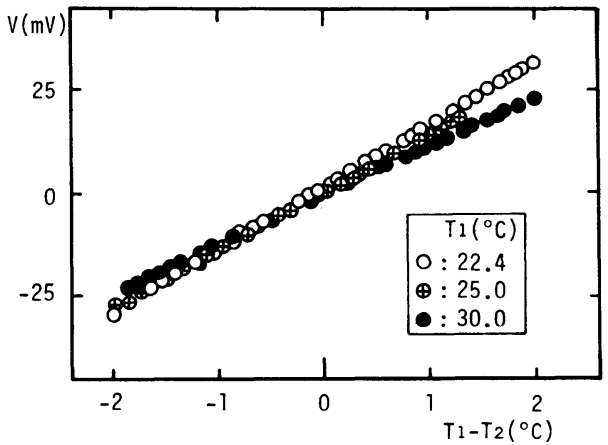

図一9 基準温度 $T_{1}$ に依存する温度差と出力值の関係

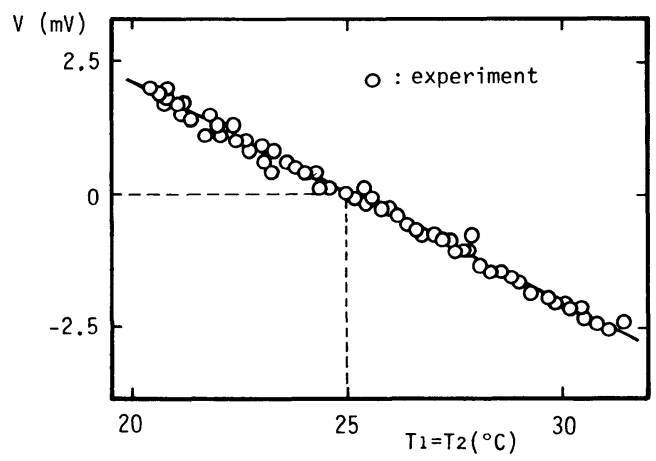

図一10 ゼロバランスの温度依存性

$\frac{V}{E}=\varepsilon$

$\frac{R_{01} \exp B_{1}\left(1 / T_{1}-1 / T_{0}\right)}{R_{02} \exp B_{2}\left(1 / T_{2}-1 / T_{0}\right)+R_{01} \exp B_{1}\left(1 / T_{1}-1 / T_{0}\right)}$

となる.したがって， $R_{0 i}, B_{i}$ が等しい場合には温度差 $T_{1}-T_{2}>0$ のとき, $V>0, T_{1}-T_{2}<0$ のとき, $V<0$ と なる．図一 9 は， $T_{1}$ を基準温度とした場合の温度差と 出力値の関係を示している. 同図から温度差 $T_{1}-T_{2}$ か $\pm 2^{\circ} \mathrm{C}$ の範囲内では温度差と出力值の間には直線関係が 成立するが，この関係は基準温度に依存し，基準温度が 低いほど出力值は大きい傾向となることがわかる．式 （9）において $T_{1}=T_{2}=T$ とし, $R_{0 i}, B_{i}$ が等しい場合 には, $V=\varepsilon-1 / 2$, となり $\varepsilon=1 / 2$ であれば出力値はゼ 口である. しかし， $B$ 值は温度によって変化し，2つの サーミスターの特性等が異なる結果, ゼロバランスの温 度依存性が生ずる. その結果を图一10に示す. 同図から， $20 \sim 30^{\circ} \mathrm{C}$ の範囲内では温度の上昇に伴って出力値が, ほぼ直線的に減少するといえよう。

b）熱源部の放熱特性

微流速中では，熱源からの加熱による自由対流が必ず しも無視できるとは限らないが, 議論の対象である流れ

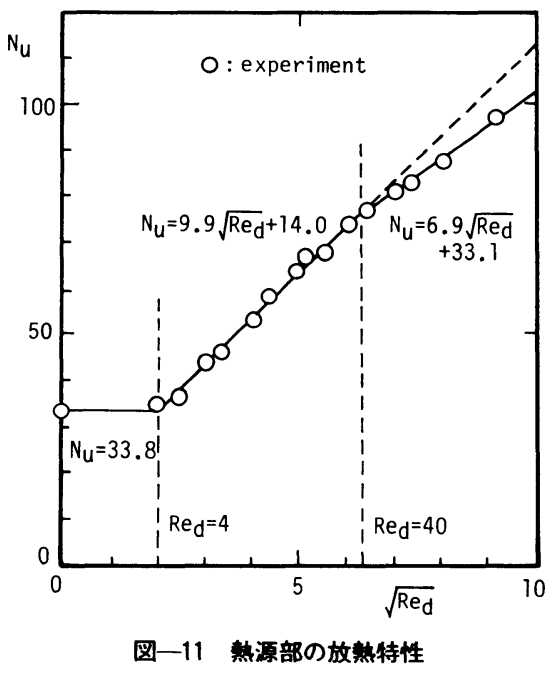

場が鉛直方向を考えない水平二次元場であることを考虑 して，ここでは熱源部からの放熱が流れによる強制対流 のみによるものとすれば流速がある程度以上では，熱伝 達の法則より無次元化された放熱量 $N_{u}$ (Nusselt) 数は, $R_{e}$ (Reynolds) 数および $P_{r}$ (Prandtl) 数の関数とし て表わすことができる．ただし， $P_{r}$ 数は物性值である から定数 $(A, B)$ の中に含めて考えると, 熱源温度が あまり高くない場合には，いわゆる King の式

$$
N_{u}=A+B \sqrt{R_{e_{d}}}
$$

が近似的に成立することが知られている12).ここで,

$$
N_{u}=\frac{(Q / A) l}{k_{f}\left(T_{w}-T_{f}\right)}, R_{e_{d}}=\frac{U d}{\nu}
$$

$Q / A$ : 熱フラックス, $l:$ 熱線長, $k_{f}$ : 流体の熱伝導係 数, $T_{w}-T_{f}$ : 熱線と流体の温度差, $U$ : 流体速度, $d$ : 熱線直径, $\nu$ : 流体の動粘性係数である.

図一11 は, 最小 2 乗法により定数を求めたうえで式 (10) の関係を示したものである． $R_{e}$ 数のごく低い範 囲を除外した $R_{e_{d}}=40$ までの範囲では $N_{u}$ と $\sqrt{R_{e_{d}}}$ 間の よい直線関係を示している．ただし， $R_{e_{d}}>40$ では渦の 放出のために熱源部の放熱特性が変化することに注意し なければならない。

c）台車による検定

上記の 2 つの検定は，温度検出部および熱源部の単独 での検定結果であり，単純に両者を重ね合わせることは できない，したがって，実際に流速計として使用する場 合には,これらを 1 組のセンサーとして種々の影響を含 めた形で流速との関係を把握しておかなければならな い.

この検定は，水路上縁のレール上を滑動可能な台車に 流速計を取り付け, 台車を無段変速モーターにより走行 させたときの流速計の出力と台車速度の関係を求めると 
(a)

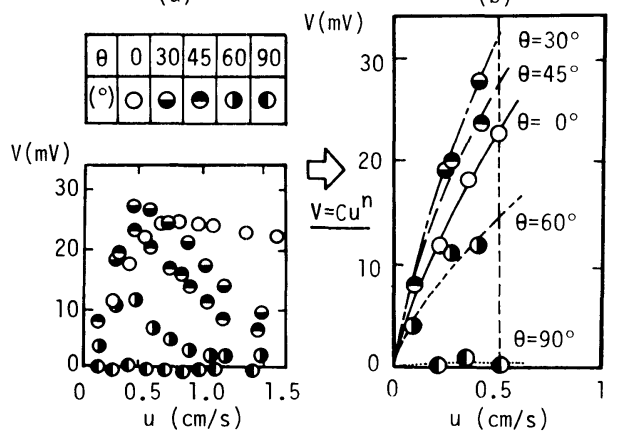

图一12 迎角の变化による流速および出力值の较正曲線

いう形で行った.

図一12 は熱源とサーミスターの中心間隔を $a=5 \mathrm{~mm}$ とし，それらの中心軸に対する流れの迎角 $\theta$ を 0,30 , $45,60,90^{\circ}$ 之変化させた場合に, 上記の方法で得られ た較正曲線を示している，ただし，プローブ支柱の影響 や製作誤差などを考慮して，それぞれの測定はすべて中 心軸を $180^{\circ}$ 回転した場合についても行い，両者の平均 值で示している，また同図には，式（3)，および $R_{0 i}$, $B_{i}$ が等しいと仮定した式（9）加求まる電位差と流 速の関係式

$$
\frac{V}{E}=\varepsilon-\frac{1}{\exp A\left(e^{\gamma_{u}}-e^{-\gamma_{u}}\right) K_{0}(\gamma u)+1}
$$

ここで, $A=(q / 2 \pi K) /\left(T_{1} \cdot T_{2} / B\right), \quad \gamma=a / 2 K$ を 0.5 $\mathrm{cm} / \mathrm{s}$ 以下の範囲に対して次の放物線式,

$$
V=C \cdot u^{n} \text {. }
$$

で近似した曲線を併記してある．ここで， $C, n(>0)$ : 定数である.

同図に示されるように，流速と電圧の関係は，ある流 速範囲を越えると 2 価関数となる. また， $\theta \neq 0^{\circ}$ のとき に出力值が最大になっていることが注目される。これは 基本的には, 熱源前後の流れ場の非対称性によるものと 思われるが，その他にもプローブ自体が流れ場を乱し， 粘性効果による渦と円柱の干渉や流れと㹡散の相互作用 が複雑に影響しているものと考えられる.

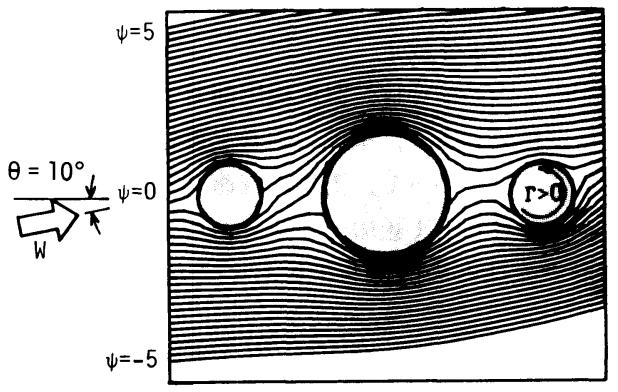

図一13 ポテンシャル理論に基つく複数円柱まわりの流線関数 $(s / d=1.25, \Gamma / W=0.5)$
流れ場の非対称性によって，こうした現象が生じる状 況は定性的にではあるが，たとえば， $\theta$ については鏡像 原理を用いたポテンシャル理論により以下のように説明 することができる，すなわち，いま一様流中に置かれた 径の異なる複数円柱まわりの流線関数を求めて ${ }^{13)}$, 流れ に対して迎角をもつ場合の流れの状態を計算した一例を 示すट図一13のようである.ただし，この計算では流 れ場に非対称性をもたせるために下流側の円柱には正の 循環 $\Gamma$ を与えている.

流れの様子は, 迎角 $\theta$, Reynolds 数および円柱間隔 比 $s / d$ ( $s$ : 円柱中心間隔， $d$ : 熱源円柱の直径）等に よって変化する ${ }^{14)}$. たとえば, $s / d$ が大きい場合には 円柱相互は影響を及ぼさず，熱源円柱まわりに流線は点 対称となる。しかし， $s / d$ が小さくなると円柱の径の 差異が影響し， $\theta \neq 0^{\circ}$ のとき，熱源より下流側の円柱間 では，熱源の径による流れの曲率の影響を受けて，上流 の円柱間よりも流量が小さくなることが予想される.し たがって, $\theta \neq 0^{\circ}$ では上流円柱間の流れのため, 上流側 の温度検出部は水温 $T_{w}$ に近い温度となり, 一方 $\theta=0^{\circ}$ では，円柱間の中心軸上によどみ点が位置するため，上 流側のそれは $T_{w}$ よりも高い温度となり, 下流側の検出 部の温度に差がなければ, $\theta=0^{\circ}$ のときよりも出力值は 大きくなることが予想される.

\section{（4）二次元流速場の推定法}

上述のように，流速と出力値の関係は非線形であり， 迎角 $\theta$ によってその特性が変化するために，いわゆる 余弦則が成立せず，図一2 を直接適用することはできな い. 一般に, 流速成分 $u, v$ は出力值 $V_{u}, V_{v}$ と次のよ うな関係にある.

$$
\begin{aligned}
& u(t)=W(t) \cdot \cos \theta=V_{u}(t)\langle X\rangle \\
& v(t)=W(t) \cdot \sin \theta=V_{v}(t)\langle Y\rangle
\end{aligned}
$$

ここで, $W^{2}=u^{2}+v^{2},\langle X\rangle,\langle Y\rangle$ は補正係数である. 問題は, 出力值から流速に換算する場合の補正係数の決 定方法である. 式 (14)，（15）において，〈X>, $\langle Y\rangle$ は $W, \theta$ の関数

$$
\begin{aligned}
& \langle X>=X(W, \theta) . \\
& \langle Y\rangle=Y(W, \theta) .
\end{aligned}
$$

となるが, 式 $(16),(17)$ を逆変換できたとすれば, $V_{u}, V_{v}$ の測定值から $X, Y$ を求め, $W, \theta$ を次のように 決定することができる.

$$
\begin{aligned}
& W=F_{w}(X, Y) \\
& \theta=F_{\theta}(X, Y) \cdots
\end{aligned}
$$

しかし，この逆変換は簡単ではなく，実際的でもないの で,検定による離散データから適当な関数をあてはめる, いわゆる回帰分析的手法によって式（18），(19）を決定 するのが得策であろう。

そこで，前述のように較正曲線が式（13）で近似でき 
(a)

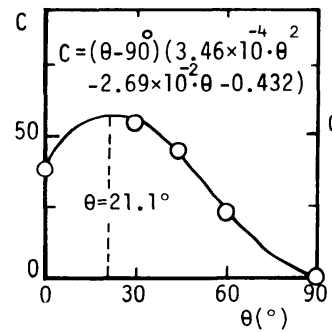

(b)

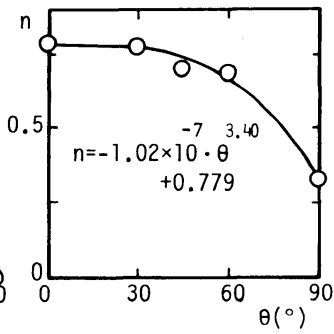

図一14 近似曲線式 (13) のパラメーター $C, n$ の迎角 による変化

る場合には, $C, n$ を $\theta$ の関数として, それぞれ 3 次関 数および放物線で近似したのが, 図一14である.

このように考えれば, 出力值 $V_{u}, V_{v}$ は,

$V_{u}=C_{u}(W \cos \theta)^{n_{u}}, \quad V_{v}=C_{v}(W \sin \theta)^{n_{v}}$

となり, $W$ を消去して, $\theta$ のみの関数

$$
f(\theta)=\left(\frac{V_{v}}{C_{v}}\right)^{1 / n_{v}}\left(\frac{C_{u}}{V_{u}}\right)^{1 / n_{u}}-\tan \theta=0
$$

が得られる. したがって, 結局, 式 (21) から $V_{u}, V_{v}$ が与えられれば, 逐次近似法などにより, まず角度 $\theta$ を求め, 式 (20) より $W$ が定まり, 流速成分 $u, v$ が 算出できることになる.

\section{4. 長周期波動場の水粒子速度の計測}

以上の検定結果を用いて, 長周期波動場における有用 性を検証するために, 簡単な水理実験を行った.

潮汐発生システムは長方形水槽 (全長 $6.5 \mathrm{~m}$, 横幅 $0.9 \mathrm{~m}$, 側壁長 $0.6 \mathrm{~m}$ ) の片側にポンプを設置し, 水の 供給量はその回転数をマイコン制御によりきわめて小刻 みに変化させて行う水供給式で,実験は水平床で行った. なお，測定点は湾口 $(x=0)$ より $x=0.5,2.0,3.5 \mathrm{~m}$ の水深中央 $z=h / 2$ である. 波形記録は, 潮汐振動開始 の第 1 10 周期までとし, 解析は時間波形が周期的に安 定状態となった第 4 9 周期目の 5 周期であり, 流速の 最大值についてはその平均値を採用している. また，流 速計の応答特性を考慮して $0.1 \mathrm{~Hz}$ のローパスフィル ターにより処理を施している. 実験諸元を表一1に示す.

本実験では，まず，差温式微流速計による点計測デー 夕を比較する目的で水素気泡法による流れの可視化も試 みた。ただし，この方法は微流速になると気泡同士が接 触・合体する危険性があり，この影響を無視できない ${ }^{15)}$.

\section{表一1 実殹諸元}

\begin{tabular}{|c||c|c|}
\hline depth $h(\mathrm{~cm})$ & period $T(\mathrm{~s})$ & tidal range $\mathrm{H}(\mathrm{cm})$ \\
\hline 10.0 & $59.8 \sim 63.8$ & $0.23 \sim 0.49$ \\
\cline { 2 - 3 } 12.5 & $87.3 \sim 92.9$ & $0.39 \sim 0.78$ \\
\cline { 2 - 3 } 15.0 & $114.8 \sim 122.3$ & $0.55 \sim 1.02$ \\
\hline
\end{tabular}

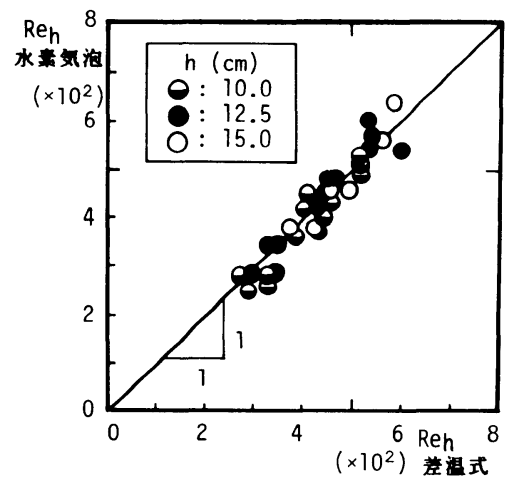

図一15 差温式微流速計および水来気泡法による最大 流速值の比較

したがって実験に際しては，パルス周期とその幅を調節 してこの影響を最小にし，白金線（直径 $0.05 \mathrm{~mm}$ ）に は適当な間隔でペイントによるコーティングを施して， 水素気泡の浮力が及ぼすひずみを修正するようにした。

図一15は, 差温式微流速計および水素気泡法による 平均流速の最大值を, 次式で表わされる水深 $h$ で無次 元化した鉛直 $R_{e}$ 数の比較を示している.

$$
R_{e_{h}}=u_{\max } \cdot h / \nu
$$

同図から $250<R_{e_{h}}<600$ の範囲では，ほぼ直線関係が 成立し, 最大流速值は対応していることが確かめられた。

次に流速の時間波形について，その応答特性をみるた めに, 式 (23) で与えられる層流境界層理論 ${ }^{16)}$ に基づく 基本振動流の流速 $u$ と比較したのが図一16(b) および

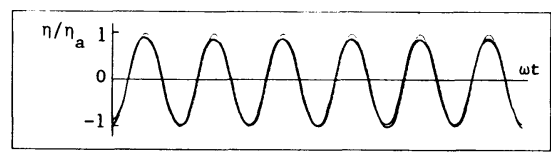

(a) wave height $(\mathrm{x}=2.0 \mathrm{~m})$

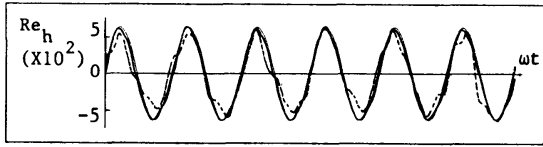

(b) velocity $(\mathrm{x}=2.0 \mathrm{~m}, \mathrm{~h}=12.5 \mathrm{~cm})$

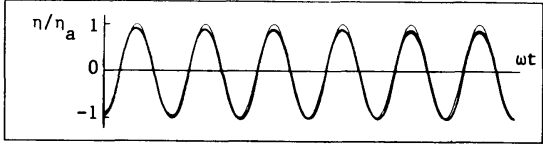

(c) wave height $(x=3.5 \mathrm{~m})$

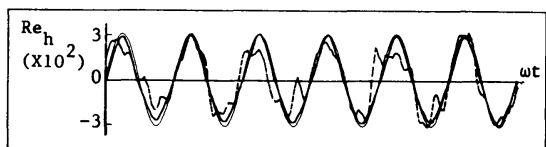

(d) velocity $(x=3.5 \mathrm{~m}, \mathrm{~h}=12.5 \mathrm{~cm})$

図一16 美温式（太い実線）および西硫速計（太い破腺）に よる計測流速と理論值（細い実腺）の時間波形 $\left(\theta=0^{\circ}\right)$ 
(d) である. 同図には参考のために電磁流速計 (アレッ ク電子 ACM-200P ）による測定値も併記した。

$$
\begin{aligned}
u\left(x^{*}, z^{*} ; t^{*}\right)= & R_{e}\left[\frac{A \eta_{a} g}{\omega}\left(P_{1}-i P_{2}\right)\left\{e^{-(1-i) z^{*}}-1\right\}\right. \\
& \left.. \frac{\sinh A\left(P_{1}-i P_{2}\right) L\left(x^{*}-1\right)}{\cosh A\left(P_{1}-i P_{2}\right) L} \cdot e^{-i t^{*}}\right]
\end{aligned}
$$

$$
\begin{aligned}
& A=\sqrt{\frac{\sqrt{1-1 / h^{*}+1 / 2 h^{*^{2}}}}{1+1 / h^{*}-1 / 2 h^{*^{2}}}} \cdot \frac{\omega}{\sqrt{g h}}, \\
& P_{1}=\sin \frac{\theta}{2}, \quad P_{2}=\cos \frac{\theta}{2}, \theta=\tan ^{-1}\left(\frac{1}{2 h^{*}-1}\right)
\end{aligned}
$$

ただし $, i=\sqrt{-1}, x^{*}=x / L, z^{*}=\beta_{z} \cdot z, \beta_{z}=\sqrt{\omega / 2 \nu}$, $h^{*}=\beta_{z} \cdot h, t^{*}=\omega t, L:$ 湾長, $h:$ 水深, $\omega$ : 角周波数, $\nu$ : 流体の動粘性係数, $g$ : 重力加速度, $\eta_{a}$ : 湾口 $(x=$ 0) での潮汐振幅である.なお，同図の縦軸は水位の最 大振幅 $\eta_{a}$ ，または鉛直 $R_{e}$ 数で，横軸は潮汐波の基本振 動周期 $T$ でそれぞれ無次元化しているが，表一1 の実 験条件を用いて $\eta_{a}=H / 2$ および $\omega=2 \pi / T$ とした。

図一16(a)，(c) は，実験中の水位の時間波形である. 同図から，水位波形はほとんど正弦波形を示しており， 式（23）の設定条件が少なくとも水位に関しては満足さ れていることがわかる.さて, 流速の時間波形をみると, 流速值が比較的大きい同図 $(\mathrm{b})\left(\left(R_{e_{n}}\right)_{\max } \fallingdotseq 600\right)$ では, 三者（理論值，差温式および電磁流速計）がほぼ一致し

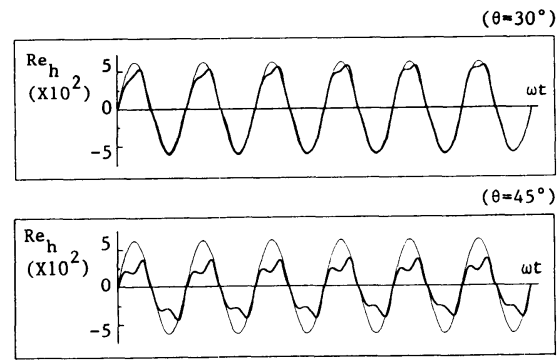

(a) $\mathrm{x}=2.0 \mathrm{~m}, \mathrm{~h}=12.5 \mathrm{~cm}$ $\left(\theta=30^{\circ}\right)$

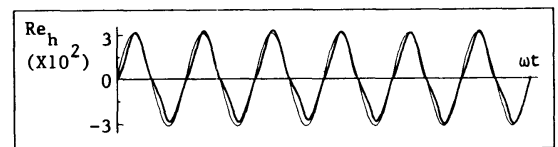

$\left(\theta=45^{\circ}\right)$

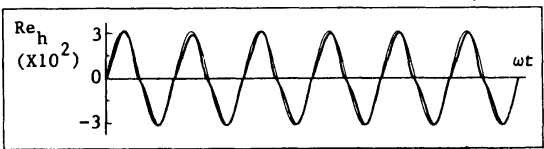

$\left(\theta=60^{\circ}\right)$

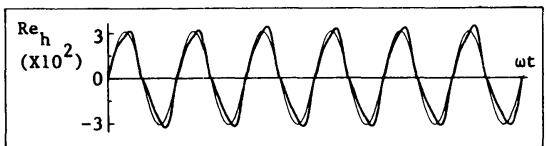

(b) $x=3.5 \mathrm{~m}, \mathrm{~h}=12.5 \mathrm{~cm}$

図一17迎角の変化による差温式微流速計の計測流速 （太い実線）と理論值（細い実線）の時間波形
ているのに対して，流速值が小さい同図 (d) $\left(\left(R_{e_{n}}\right)_{\max }\right.$ ○300）では，電磁流速計による測定値が他の二者とか なり異なっている．すなわち，電磁流速計による測定値 は正弦波形から相当ずれ，しかも周期性も崩れている. 流れ場を支配する 1 つの要因である水位波形について は，図（c）にみられるように正弦波形を保っているの であるから，この原因としては，そもそもこの場合の流 速が電磁流速計の限界以下であったことに起因するもの と考えられる. 一方, 本流速計による測定伹は理論値と 同様安定した正弦波形を示している．この場合の実験条 件が潮汐波の波長に比べて湾長が十分短く，したがって 完全重複波と考えられ，また，常に層流場で行われてい ることから波形が正弦波であれば, 式 (23) の誘導過程 が要求する流れ場は安定して形成されているものと考え られる. また周期性については, 本流速計の生デー夕 (0.1 Hz の low pass filter で処理を施す前) の時間波 形をみても，周期性の強い流れ場が形成されているもの と判断した. 以上のことから, 本流速計は, 流速值が比 較的大きくなる場合はもちろん，常に微流速で振動する 長周期波動場においても，トレンドはきわめて小さく安 定性が高いといえよう。

また，图一17は流速計が主流に対して迎角 $\theta$ をもつ 場合の，各較正曲線を用いて換算した流速の時間波形を 示している. 同図から $\left(R_{e_{h}}\right)_{\max } \fallingdotseq 600$ では, $\theta=30^{\circ}$ 程度 から角度の増加につれて流速の最大値付近で出力値が低 下し, 流速計の指向性は低下するが, $\left(R_{e_{n}}\right)_{\max } \fallingdotseq 300$ では, $\theta=45^{\circ}$ 程度までは理論値とよく対応していることがわ かる. 同図 (a) の $\theta=45^{\circ}$ の場合のように, 流速波形の ピーク周辺で測定値がひずむのは, 前述のように, $\theta$ の 増加とともに一価関数の成立する流速範囲は狭くなり, 実際の流れがその範囲を越えているために，現象の値を 正しく測定することができなかったものと思われる．ま た，同図 (b) の $\theta=45^{\circ}$ をれば, 図 (a)に比べ実際 の流速値が一価関数の成立する範囲内であるために十分 測定可能であることを示している. したがって，3.(4) で述べた二次元流速場を推定するにあたっては, 実際の 流速值を概略把握し, 指向性に留意しながら行う必要が ある.

以上, 層流境界層に起因する潮汐残渣流の生成・維持 機構を解明する目的で, きわめて特殊な流速計を除いて 従来は計測が困難であった微流速のオイラ一的計測を 行った結果, $R_{e_{h}}<600$ 程度の範囲では, 十分な精度で 基本振動成分を検出できることを示した。

\section{5. 結 論}

以上，緩流域の流速を測定するために考案した差温式 微流速計について, その基本特性を検討するとともに長 
周期波動による流れ場においてその適用性を検証した。

本研究で得られた主要な結論を列挙すれば以下のよう である。

（1）差温式微流速計の作動原理を理論的に検討した 結果, 本流速計は原理的に流速が小さくなるほど, 流速 に対する温度差の変化率が大きく, 流速が小さいほど流 速計としての感度が高くなることが示された。

（2）流速計の応答特性として時定数を調べた結果, 速度変化に対して敏感に応答し，ほとんど時間遅れなし でとらえることができるが，その絶対值を求める場合に は流速計の夕イムラグを考虑し， $0.1 \mathrm{~Hz}$ の low pass filterで処理すればよいことがわかった。したがって， 対象亡する潮汐波の周期はそれよりも長いものであるこ とが必要である.

（3）基本的検定として温度検出部および熱源部の放 熱特性の検定を必要とするが，実用上は通常の流速検定 と同様に一定速度で走行する検定台車で較正曲線を作れ ばよいことを示した。 その場合, 較正曲線が 2 価関数と なる問題はあるが，一般には流速の概略值については事 前に知り得ることを考えれば, 致命的な欠点とは考えら れない。

（4）一般的な二次元流速場での測定法を示した.

（5）現実の長周期波動場における有用性を検証する ために，簡単な水理実験を行った結果，任意点の流速の 最大值に対しては, 差温式微流速計による測定値と水素 気泡法によるものとはほぼ一致することが示された。な お，振動流の時間波形の連続記録という観点からは，前 者の方が有利であることはいうまでもない.

（6）従来, きわめて特殊な流速計を除いて, 計測が 困難であった微流速のオイラー的計測を行った結果, $R_{e_{h}}<600$ 程度では振動流の基本成分を十分にとらえて いることが示された。

（７）なお，本流速計の斜流特性には若干問題がある ので，二次元流速場に適用する際は，実際の流速場をあ らかじめ概略把握し，指向性を検討したうえで行う必要 がある。

本流速計は潮汐の流れ，あるいはそれに基づく残渣流 の測定というきわめて限定された流れの計測のために製 作されたものであって，応答特性が非線形になるなどの 点はあるが，緩慢に変化するきわめて小さい流速の計測 には十分の信頼性があるものと判断している.

なお，明らかなように差温式微流速計は，流体の乱流 計測などのように高周波成分が必要となる場合には適さ ない. しかし上記のように低 Reynolds 数 $\left(R_{e_{h}}<600\right)$ の範囲では, トレンドも無視できるほど小さく, 十分安 定している点が優れている. 今後は，さらに改良を加え
て, 流速值の適用範囲を拡大するとともに潮汐残渣流の 生成・維持機構に関する詳細な研究に応用していきたい と考えている.

最後に, 本研究を進めるに際し耐えず有益なご助言を 賜った名古屋大学工学部土木工学科 岩田好一朗教授な らびに差温式微流速計についての情報を提供して下さっ た豊橋技術科学大学工学部建設工学系 開発一郎氏, に 深く感謝する.

\section{参 考 文 献}

1）樋口明生：潮流模型における乱流度に関する一考察, 京 都大学防災研究所年報, 第 15 号 B, pp. 425 430, 1972.

2) 今里哲久・佐藤 敏：沿岸の潮汐・潮流の数值実験, 海 洋科学, Vol. 18, No.7, pp. 464 470, 1986.

3）たとえば，中村俊六・足立昭平：緩流段落与部後流域に おける流速測定法について, 土木学会論文報告集, 第 220 号, pp. $65 \sim 70,1973$.

4）たとえば，日本機械学会：技術資料「流体計測法」，1985.

5）谷口真人・佐倉保夫・古藤田一雄：差温式微流速計によ る水分フラックスの測定, 筑波大学水理実験センタ一報 告, No. 6, pp. 87 92, 1982.

6) Kawanishi, H. : A Microflowmeter for Soil Water in Unsaturated Zone, Research Bull. Fac. Edu., Oita Univ., Vol.4, pp. 17 27, 1975.

7) Byrne, G. F., Drummond, J. E. and Rose, C. W. : A Sensor Water Flux in Soil. 1. "Point Source" Instrument, Water Resources Research, Vol.3, pp. 1073 1078, 1967.

8) Byrne, G. F., Drummond, J. E. and Rose, C. W. : A Sensor Water Flux in Soil. 2. "Line Source" Instrument, Water Resources Research, Vol.4, pp.607 $611,1968$.

9）堀部純男編：環境科学としての海洋学 2, 東京大学出版 会, pp. 215 231， 1978.

10) Collins, D. C. and Williams, M. J. : Two-dimensional convection from heated wires at low Reynolds numbers, J. Fluid Mech., Vol. 6, pp. 357 384, 1967.

11）自動化技術編集部編：やさしいセンサ技術, 工業調査会, pp. 134 144, 1982.

12）今本博健：開水路流れの乱れに関する水理学的研究, 京 都大学学位論文，第 II 編，pp. 1 11，1971.

13) Carpenter, L. H. : On the Motion of Two Cylinders in an Ideal Fluid, J. of Research of the National Bureau of Standards, Vol.61, pp. 83 87, 1958.

14）たとえば, 日本機械学会編：写真集「流れ」, pp. 1 5, 1984.

15）称津家久：開水路流の乱流構造に関する基礎的研究, 京 都大学学位論文, 第 3 章, pp. 25 32, 1977.7.

16）安田秀一：境界層による潮汐残渣流（その方程式之湾長 が任意の場合の解)，中国工業技術試験所報告, No. 19, pp. $67 \sim 86,1983$.

(1987.2.14 • 受付) 